\title{
Comparison of lateral versus triceps-splitting posterior approach in the surgical treatment of pediatric supracondylar humerus fractures
}

\author{
Faik Türkmen, M.D., ${ }^{1}$ Serdar Toker, M.D., ${ }^{1,2}$ Kayhan Kesik, M.D., ${ }^{1}$ \\ İsmail Hakkı Korucu, M.D., ${ }^{1}$ Mehmet Ali Acar, M.D., ${ }^{3}$
}

${ }^{1}$ Department of Orthopaedics and Traumatology, Necmettin Erbakan University Meram Faculty of Medicine, Konya-Turkey ${ }^{2}$ Department of Hand and Upper Extremity Surgery Division, Necmettin Erbakan University Meram Faculty of Medicine, Konya-Turkey ${ }^{3}$ Department of Orthopaedics and Traumatology, Selçuk University Faculty of Medicine, Konya-Turkey

\begin{abstract}
BACKGROUND: Supracondylar humerus fracture is the most common fracture of the elbow in children. Closed reduction and percutaneous pinning is considered to be the optimal treatment strategy; however, in some instances, open reduction may be necessary. The aim of this retrospective study was to compare clinical and functional results of triceps-splitting posterior versus lateral approach in pediatric supracondylar humerus fracture surgery.
\end{abstract}

METHODS: A total of 38 patients underwent surgery; Group I consisted of 30 patients on whom posterior approach was used, while lateral approach was used on the 8 patients in Group 2. Flynn criteria were used to evaluate cosmetic and clinical results. Fracture healing was assessed with anteroposterior and lateral x-rays. Patients and parents were asked to describe time needed for complete return of full elbow range of motion (ROM) and overall satisfaction.

RESULTS: Mean fracture union time was 44.1 days and 46.3 days, and time required to regain complete or near complete elbow ROM was 57.5 days and 55.7 days after splint removal for Group I and Group 2, respectively. Twenty-one of 30 (70\%) patients (and parents) in Group I, and 6 of 8 (75\%) patients (and parents) in Group 2 were totally satisfied with the results. Twenty-one of 30 (70\%) patients in Group I, and 6 of 8 (75\%) patients in Group 2 had excellent cosmetic and functional results according to Flynn outcome criteria.

CONCLUSION: In cases of pediatric supracondylar humerus fracture, early closed reduction and percutaneous pinning is preferred; however, when this method is not applicable, triceps-splitting posterior approach is a safe and comparable method to lateral approach with advantages of easier fracture reduction and shorter operating time.

Keywords: Posterior approach; supracondylar humerus fracture; triceps.

\section{INTRODUCTION}

Supracondylar humerus fracture is the most common fracture encountered in children. ${ }^{[1-3]}$

Closed reduction and percutaneous pinning is considered the

Address for correspondence: Faik Türkmen, M.D.

Necmettin Erbakan Üniversitesi Meram Tıp Fakültesi,

Ortopedi ve Travmatoloji Anabilim Dalı, 42090 Konya, Turkey

Tel: +90 332 - 2236230 E-mail: turkmenfaik@gmail.com

Qucik Response Code Ulus Travma Acil Cerrahi Derg

2016:22(5):483-488
doi: $10.5505 /$ tjtes.2016.74606

Copyright 2016

TJTES optimal treatment for most supracondylar fractures. ${ }^{[4]}$ However, open reduction may be necessary in cases of irreducible fragments, open fractures, or when there is neurovascular injury. ${ }^{[5-7]}$ Lateral, medial, or posterior approach may be used. ${ }^{[8]}$ Posterior approach is an easy approach, but it is not usually recommended due to complications such as osteonecrosis of the trochlea ${ }^{[2]}$ or stiffness due to wide dissection. ${ }^{[9,10]}$ Some authors, however, have stated that there was no significant difference in clinical results. ${ }^{\left[{ }^{1 I}\right]}$ The aim of this retrospective study was to compare the clinical and functional results of posterior versus lateral approach in surgical treatment of pediatric supracondylar humerus fracture.

\section{MATERIALS AND METHODS}

The institutional review board approved the chart review for this study, and informed consent was obtained from all pa- 
tients. Medical records of 138 children with supracondylar humerus fracture who were operated on at the institution between January 2008 and November 2013 were retrospectively reviewed.

Patients with Gartland Type III fractures ${ }^{[12]}$ who underwent open reduction with either posterior or lateral approach and cross-pin fixation were included in the study. Exclusion criteria were open fracture or fracture of the ipsilateral upper limb, inadequate radiographs, incomplete data, or loss to follow-up.

A total of 38 patients ( 23 boys and 15 girls) matched these criteria. Mean age of patients at the time of surgery was 7.8 years (range: $5.1-12.7$ years), and mean follow-up time was 4.2 years (range: I.4-7.2 years) (Table I).

All patients underwent surgery on the day of fracture under general anesthesia and in a supine position. Approach was chosen based on the surgeon's experience. For posterior approach, after application of tourniquet, a $5 \mathrm{~cm}$ skin incision was made beginning $2 \mathrm{~cm}$ superior to olecranon and extending proximally on midline of the arm. Triceps fascia was cut and bone exposed by splitting triceps muscle on midline. Reduction of fracture under direct visualization was followed by repair with 2 or 3 cross K-wires, I or 2 from lateral epicondyle and I from medial epicondyle (Fig. Ia, b). Triceps muscle and fascia were repaired with 4 to 5 interrupted absorbable sutures and then skin was closed. Long arm splint was applied for 4 weeks. Pins were extracted in the clinic 2 weeks after splint removal. For lateral approach, a 4 to $5 \mathrm{~cm}$ skin incision over lateral bony prominence was made and fracture was exposed, but since direct visualization in this approach was not complete (Fig. 3), indirect fracture reduction was performed by manipulation with fingers and tools. For medial pin inser-
Table I. Demographic data of the groups

\begin{tabular}{lcc}
\hline Groups & Group I & Group2 \\
\hline Number of patients & 30 & 8 \\
Mean age (years) & 7.8 & 7.9 \\
Girl/boy ratio & $12 / 18$ & $3 / 5$ \\
Mean follow-up time (months) & 50.32 & 50.41 \\
\hline
\end{tabular}

tion, a $2 \mathrm{~cm}$ incision was made on medial epicondyle, condyle was exposed, and pin was placed directly in the humerus in order to protect ulnar nerve. Remainder of operation and follow-up period was the same as for posterior approach.

Patient outcomes were evaluated using Flynn criteria ${ }^{[5]}$ at final follow-up visit (Table 2).

Complications such as reduction loss, pin migration, infection, osteonecrosis of any part of the elbow, bone healing, and functional results were evaluated.

Plain anteroposterior and lateral radiographs of the elbow taken on first postoperative day and date of pin removal were used to assess loss in reduction (Figs. $2 a, b$ and $3 a, b$ ). Patients and parents were also asked about overall satisfaction.

Statistical methods designed for independent observations were used. Mean and standard deviation were calculated. Non-continuous variables were compared using chi-square test, and Spearman's correlation analysis was applied to test associations of variables. Relationship between clinical outcome and range of motion (ROM) at final follow-up were evaluated with Mann-Whitney $U$ test. All analyses were per-
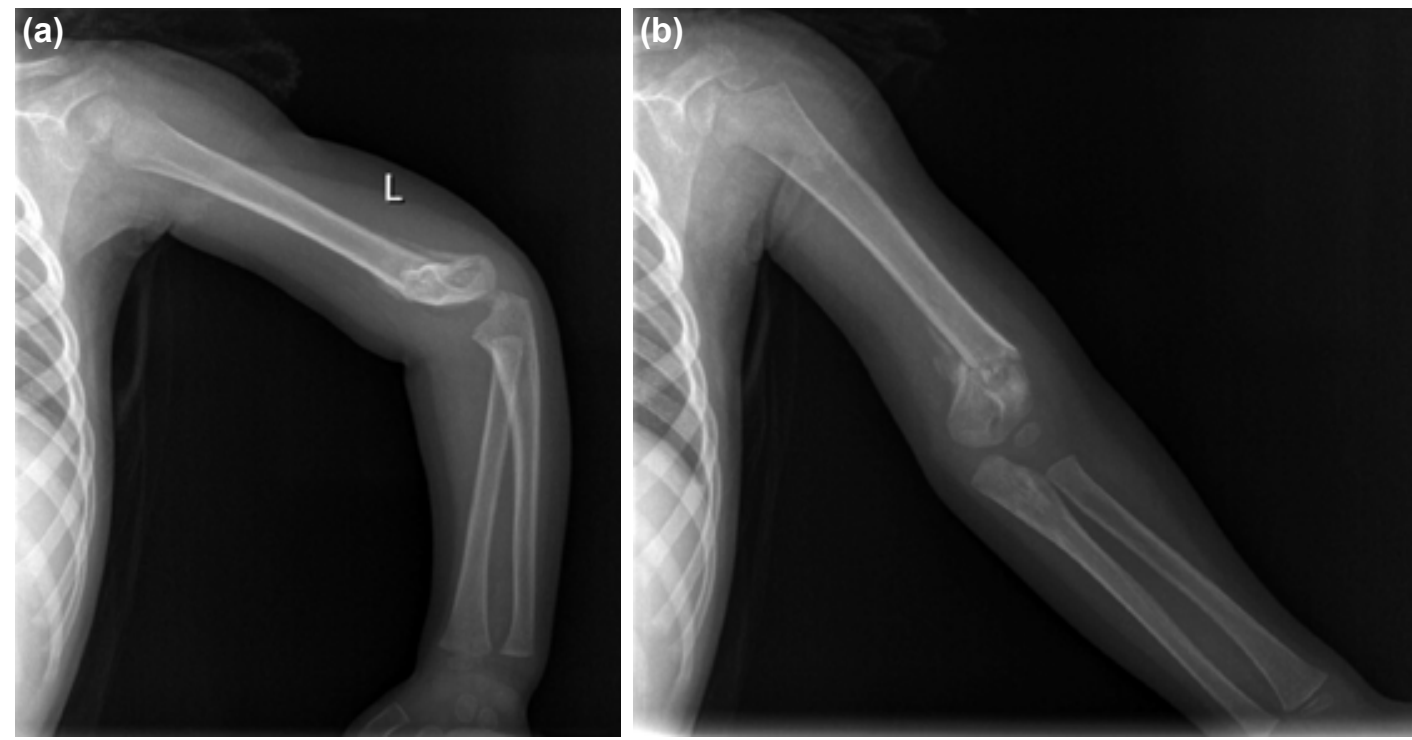

Figure 1. (a, b) Anteroposterior and lateral view of the left elbow of a 9-year-old girl with a supracondylar humerus fracture that occurred in a fall on outstretched hand and extended elbow. 

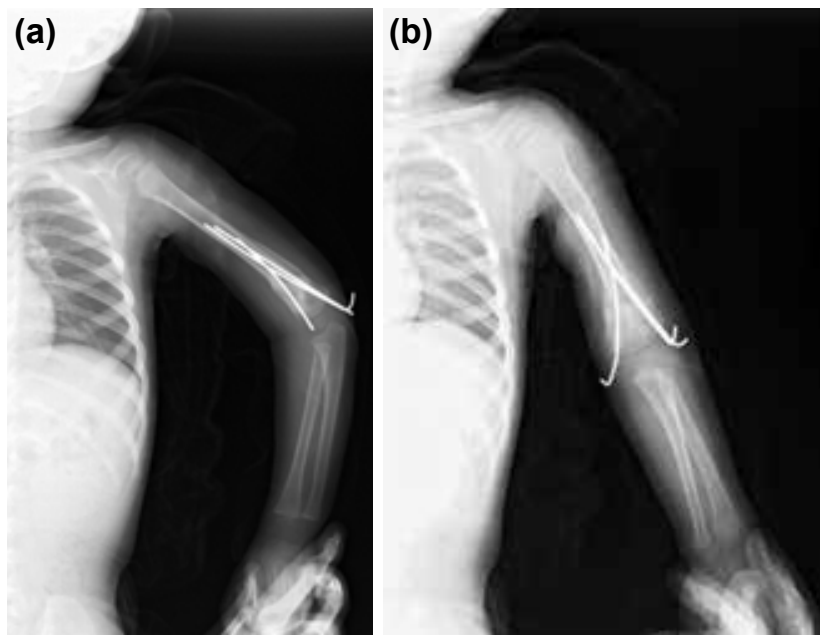

Figure 2. (a, b) Anteroposterior and lateral x-rays taken at the fourth week following surgery.

formed using SPSS statistical software (version 21.0; SPSS Inc., Chicago, IL, USA).

\section{RESULTS}

There were 36 Gartland type III fractures and 2 type II fractures in the study. No loss of reduction, pin migration, osteonecrosis, or nonunion was recorded. Superficial pin infection was noted in 3 patients: 2 patients in Group I and I patient in group 2, which were resolved with oral antibiotic treatment and saw no additional complication. All fractures healed uneventfully.
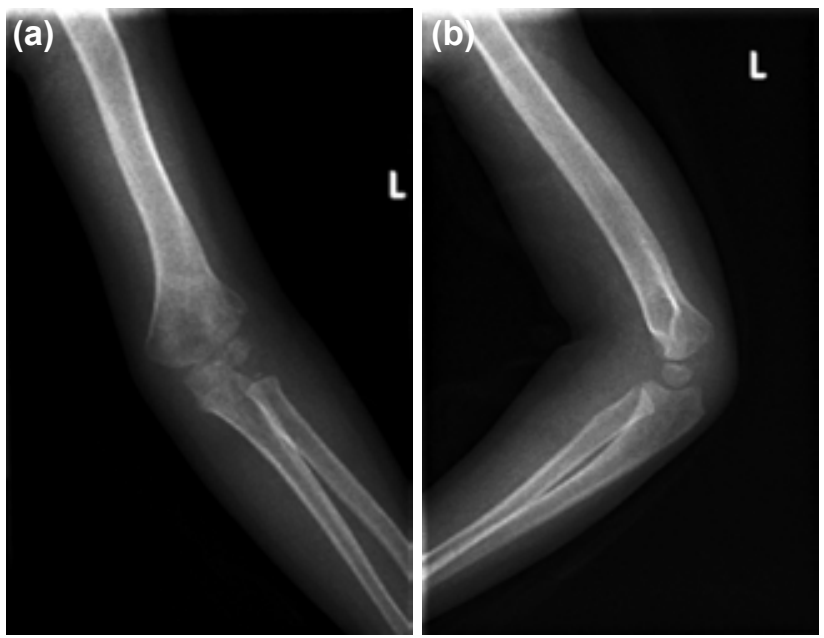

Figure 3. (a, b) Anteroposterior and lateral x-rays taken after pin extraction in the clinic at sixth week after surgery.

Mean splinting period was 31.97 days (range: 26-44 days) for Group I, and 31.75 days (range: 24-4I days) for Group 2. The difference is not statistically significant $(p<0.05)$.

Pin removal took place upon fracture union. Mean fracture union time was 44.1 days and 46.3 days, and time for complete or near complete return of the elbow ROM was 57.5 days and 55.7 days after splint removal for Group I and Group 2, respectively. These differences were not statistically significant $(p<0.05)$.

Twenty-one of 30 (70\%) patients (and parents) in Group I,

Table 2. Flynn criteria ${ }^{[5]}$ for grading results

\begin{tabular}{llcc}
\hline Results & Rating & $\begin{array}{c}\text { Cosmetic factor: } \\
\text { Loss of carrying angle (degrees) }\end{array}$ & $\begin{array}{c}\text { Functional factor: } \\
\text { Loss of motion (degrees) }\end{array}$ \\
\hline Satisfactory & Excellent & $0-5$ & $0-5$ \\
& Good & $6-10$ & $6-10$ \\
& Fair & $11-15$ & $11-15$ \\
Unsatisfactory & Poor & $>15$ & $>15$ \\
\hline
\end{tabular}

Table 3. Statistical analysis of differences between the 2 groups in length of time to achieve fracture union, patient and parent satisfaction, Flynn cosmetic and functional criteria, and time required to regain full elbow range of motion. None of the differences were found to be statistically significant

\begin{tabular}{lccc}
\hline Groups & Group I & Group 2 & p \\
\hline Fracture healing (days) & $44.1(30-56)$ & $46.3(40-55)$ & $<0.05$ \\
Full satisfaction & $21 / 30(70 \%)$ & $6 / 8(75 \%)$ & $<0.05$ \\
Flynn cosmetic & $21 / 30(70 \%)$ & $6 / 8(75 \%)$ & $<0.05$ \\
Flynn functional & $21 / 30(70 \%)$ & $6 / 8(75 \%)$ & $<0.05$ \\
Complete range of motion (days) & $57.5(40-70)$ & $55.5(50-65)$ & $<0.05$ \\
\hline
\end{tabular}


Table 4. Spearman's correlation analysis of relationship between variables. Numbers are r-values and negative numbers show counter correlation

\begin{tabular}{lcccc}
\hline Variable & Flynn criteria & Time for union & Time for ROM & Gartland type \\
\hline Satisfaction & -1 & -4.65 & -5.29 & Not significant \\
Time for union & -4.65 & Not applicable & 0.86 & Not significant \\
Splinting time & Not significant & 0.38 & 0.39 & Not significant \\
Age & Not significant & Not significant & Not significant & 0.39
\end{tabular}

ROM: Range of motion.

and 6 of 8 (75\%) patients (and parents) in Group 2 were totally satisfied with the results; there was no statistically significant difference between groups $(p<0.05)$.

According to Flynn cosmetic and functional criteria, all the results were satisfactory; there were no fair or poor scores. As in the patient satisfaction assessment, 2 I of $30(70 \%)$ patients in Group I, and 6 of 8 (75\%) patients in Group 2 had excellent cosmetic and functional outcomes according to the ranking criteria. Differences in all these results were not statistically significant $(p<0.05)$ (Table 3$)$.

Correlation between variables was evaluated using Spearman's correlation analysis. Full satisfaction was negatively correlated with Flynn criteria (Flynn score of $\mathrm{I}$ is excellent, 2 is good), and negatively correlated with fracture union and length of time to full ROM. Time required to achieve full ROM was correlated with fracture union time and splinting time. Age was correlated with Gartland classification; older children had highest level of classification (type III) (Table 4).

\section{DISCUSSION}

Supracondylar humerus fracture is the most common surgically treated fracture seen during childhood. ${ }^{[13]}$ Treatments for displaced supracondylar humerus fracture are closed reduction and internal fixation or open reduction and internal fixation, ${ }^{[13]}$ and numerous surgical techniques have been described in the literature. ${ }^{[13,14]}$ Anatomical reduction and stable fixation with good cosmetic appearance and full ROM are the treatment goals. ${ }^{[7,9]}$ Closed reduction and percutaneous pinning is the commonly accepted primary method of treatment. ${ }^{[13,14]}$ Under some conditions, however, such as soft tissue entrapment, severely displaced fracture, very edematous elbow, open fracture, or neurovascular injury, open reduction may be required. ${ }^{[5-7,15,16]}$

A lateral, medial, anterior, or posterior approach can be used for open reduction. ${ }^{[8,17]}$ Most surgeons prefer medial or lateral approach, ${ }^{[5,18]}$ but anterior approach is also a safe and simple method. ${ }^{[6,19,20]}$ Though lateral approach is widely used, it has been stated that unsatisfactory reduction, and therefore objectionable clinical results, are of high probability in cases of exploration of only one cortex. ${ }^{[21]}$
There is a scarcity in the literature about posterior approach for pediatric supracondylar fracture surgery. There are a few reports describing posterior exposure; however, fracture sites were reached via lateral or medial paratricipital approach, ${ }^{[9,22]}$ or through a tongue-shaped flap of the aponeurosis with division of the remaining muscle fibers. ${ }^{[10]}$ In these approaches, the surgeon must find and protect the ulnar nerve, which prolongs operation time. ${ }^{[9,10,22]}$ Additionally, risk of neuropraxia is higher with exploration of the nerve rather than keeping it safely in cubital tunnel, since ulnar nerve palsies after open reduction are usually a traction injury. ${ }^{[23]}$ In Group I of the present study, the triceps was split on the midline, allowing direct access to the fracture site and easy reduction of fracture. Ulnar nerve exploration and protection were not required since pin insertion could be directly observed.

Splitting the triceps muscle provides wide exposure; however, it has been stated that cutting the muscle prevents early rehabilitation and therefore extension loss is common. ${ }^{[24]}$ The immobilization period is usually 2-4 weeks after all types of pediatric supracondylar surgeries. Mean immobilization period was about 32 days in present study groups, so authors suggest that splitting the triceps for several centimeters does not prevent routine rehabilitation. It may be true for adults, however, because of a wider approach for distal humerus fracture and probably a longer immobilization period.

Traditionally, acute treatment of pediatric supracondylar fractures within 8 hours of the trauma is recommended in order to decrease risk of complications such as compartment syndrome, infection, and nerve injury, as well as to prevent increased swelling. ${ }^{[10,11,25]}$ Poor results after open reduction and fixation are believed to be result of delay in treatment. ${ }^{[26]}$ Present study operations were all performed on first day of admission, which likely contributed to low rate of complications ( 3 superficial pin infections).

A weakness of this study may be imbalance in the number of group participants; however, statistical analysis was possible. Clinical outcomes and Flynn criteria were recorded by different residents on duty in the clinic, which could have affected the evaluation process. We found better results than expected with no poor outcomes. However, satisfaction was rated 
by the patient and the parents, and these results correlated with clinical outcomes and Flynn criteria. Another weakness of the study is that we did not perform any measurements on last x-rays. Humeral-ulnar angle, ${ }^{[23]}$ Baumann's angle, and lateral humerocapitellar angle ${ }^{[3]}$ are among the measurements that can be used to evaluate accuracy of reduction and alignment of the extremity. Additionally, we did not record operation time, but since ulnar nerve was only explored in lateral approach, posterior approach may be more advantageous in terms of length of time required for surgery.

In summary, like many authors, we believe that early closed reduction and percutaneous pinning is the optimal choice of treatment for pediatric supracondylar humerus fracture. When this method is not applicable, triceps-splitting posterior approach is a safe and comparable method to lateral approach with advantages of easier fracture reduction and shorter operation time.

\section{Conflict of interest: None declared.}

\section{REFERENCES}

1. Pescatori E, Memeo A, Brivio A, Trapletti A, Camurri S, Pedretti L, et al. Supracondylar humerus fractures in children: a comparison of experiences. J Pediatr Orthop B 2012;21:505-13. Crossref

2. Ladenhauf HN, Schaffert M, Bauer J. The displaced supracondylar humerus fracture: indications for surgery and surgical options: a 2014 update. Curr Opin Pediatr 2014;26:64-9. Crossref

3. Kao HK, Yang WE, Li WC, Chang CH. Treatment of Gartland type III pediatric supracondylar humerus fractures with the Kapandji technique in the prone position. J Orthop Trauma 2014;28:354-9. Crossref

4. Gartland JJ. Management of supracondylar fractures of the humerus in children. Surg Gynecol Obstet 1959;109:145-54.

5. Ersan O, Gonen E, İlhan RD, Boysan E, Ates Y. Comparison of anterior and lateral approaches in the treatment of extension-type supracondylar humerus fractures in children. J Pediatr Orthop B 2012;21:121-6.

6. Cramer KE, Devito DP, Green NE. Comparison of closed reduction and percutaneous pinning versus open reduction and percutaneous pinning in displaced supracondylar fractures of the humerus in children. J Orthop Trauma 1992;6:407-12. Crossref

7. Basaran SH, Ercin E, Bilgili MG, Bayrak A, Cumen H, Avkan MC. A new joystick technique for unsuccessful closed reduction of supracondylar humeral fractures: minimum trauma. Eur J Orthop Surg Traumatol 2015;25:297-303. Crossref

8. Koudstaal MJ, De Ridder VA, De Lange S, Ulrich C. Pediatric supracondylar humerus fractures: the anterior approach. J Orthop Trauma 2002;16:409-12. Crossref

9. Bombaci H, Gereli A, Küçükyazici O, Görgeç M, Deniz G. The effect of surgical exposure on the clinic outcomes of supracondylar humerus fractures in children. Ulus Travma Acil Cerrahi Derg 2007;13:49-54.

10. Lal GM, Bhan S. Delayed open reduction for supracondylar fractures of the humerus. Int Orthop 1991;15:189-91. Crossref

11. Gürkan V, Orhun H, Akça O, Ercan T, Ozel S. Treatment of pediatric displaced supracondylar humerus fractures by fixation with two cross $\mathrm{K}$ wires following reduction achieved after cutting the triceps muscle in a reverse V-shape]. Acta Orthop Traumatol Turc 2008;42:154-60. Crossref

12. Flynn JC, Matthews JG, Benoit RL. Blind pinning of displaced supracondylar fractures of the humerus in children. Sixteen years' experience with long-term follow-up. J Bone Joint Surg Am 1974;56:263-72.

13. Omid R, Choi PD, Skaggs DL. Supracondylar humeral fractures in children.J Bone Joint Surg Am 2008;90:1121-32. Crossref

14. Ay S, Akinci M, Kamiloglu S, Ercetin O. Open reduction of displaced pediatric supracondylar humeral fractures through the anterior cubital approach. J Pediatr Orthop 2005;25:149-53. Crossref

15. Kazimoglu C, Cetin M, Sener M, Aguş H, Kalanderer O. Operative management of type III extension supracondylar fractures in children. Int Orthop 2009;33:1089-94. Crossref

16. Diri B, Tomak Y, Karaismailoğlu TN. The treatment of displaced supracondylar fractures of the humerus in children (an evaluation of three different treatment methods). Ulus Travma Acil Cerrahi Derg 2003;9:629.

17. Aktekin CN, Toprak A, Ozturk AM, Altay M, Ozkurt B, Tabak AY. Open reduction via posterior triceps sparing approach in comparison with closed treatment of posteromedial displaced Gartland type III supracondylar humerus fractures. J Pediatr Orthop B 2008;17:171-8.

18. Reitman RD, Waters P, Millis M. Open reduction and internal fixation for supracondylar humerus fractures in children. J Pediatr Orthop 2001;21:157-61. Crossref

19. Danielsson L, Pettersson H. Open reduction and pin fixation of severely displaced supracondylar fractures of the humerus in children. Acta Orthop Scand 1980;51:249-55. Crossref

20. Gosens T, Bongers KJ. Neurovascular complications and functional outcome in displaced supracondylar fractures of the humerus in children. Injury 2003;34:267-73. Crossref

21. Weiland AJ, Meyer S, Tolo VT, Berg HL, Mueller J. Surgical treatment of displaced supracondylar fractures of the humerus in children. Analysis of fifty-two cases followed for five to fifteen years. J Bone Joint Surg Am 1978;60:657-61.

22. Young S, Fevang JM, Gullaksen G, Nilsen PT, Engesæter LB. Parent and Patient Satisfaction after Treatment for Supracondylar Humerus Fractures in 139 Children: No Difference between Skeletal Traction and Crossed Pin Fixation at Long-Term Followup. Adv Orthop 2012;2012:958487. Crossref

23. Ozkoc G, Gonc U, Kayaalp A, Teker K, Peker TT. Displaced supracondylar humeral fractures in children: open reduction vs. closed reduction and pinning. Arch Orthop Trauma Surg 2004;124:547-51. Crossref

24. Gruber MA, Hudson OC. Supracondylar fracture of the humerus in childhood. End-result study of open reduction. J Bone Joint Surg Am 1964;46:1245-52.

25. Harris IE. Supracondylar fractures of the humerus in children. Orthopedics 1992;15:811-7.

26. Ababneh M, Shannak A, Agabi S, Hadidi S. The treatment of displaced supracondylar fractures of the humerus in children. A comparison of three methods. Int Orthop 1998;22:263-5. Crossref 


\section{Pediatrik suprakondiler humerus kırıklarının tedavisinde trisepsi kesen posterior ve lateral yaklaşımın karşılaştırılması \\ Dr. Faik Türkmen, ${ }^{1}$ Dr. Serdar Toker, ${ }^{1,2}$ Dr. Kayhan Kesik, ${ }^{1}$ Dr. İsmail Hakkı Korucu, ${ }^{1}$ Dr. Mehmet Ali Acar ${ }^{3}$}

${ }^{1}$ Necmettin Erbakan Üniversitesi Meram Tıp Fakültesi, Ortopedi ve Travmatoloji Anabilim Dalı, Konya

${ }^{2}$ Necmettin Erbakan Üniversitesi Meram Tıp Fakültesi, El ve Üst Ekstremite Cerrahisi Bilim Dalı, Konya

${ }^{3}$ Selçuk Üniversitesi Tıp Fakültesi, Ortopedi ve Travmatoloji Anabilim Dalı, Konya

AMAÇ: Suprakondiler humerus kırıkları çocukluk döneminin en sık dirsek kırığıdır. Kapalı redüksiyon ve perkütan çivileme altın standart tedavi olarak kabul edilir. Bununla beraber bazen açık redüksiyon gerekebilir. Bu geriye dönük çalışmamızın amacı suprakondiler humerus kırıklarında triseps kasını kesen posterior ve lateral yaklaşımların klinik ve fonksiyonel sonuçlarını karşılaştırmaktır.

GEREÇ VE YÖNTEM: Toplam 38 hasta posterior veya lateral insizyonla ameliyat edildi. Grup I'de posterior insizyonlu 30 hasta, Grup 2'de lateral insizyonlu sekiz hasta mevcuttu. Kozmetik ve klinik sonuçları karşılaştırmak için Flynn kriterleri kullanıldı. Kırık kaynaması AP ve lateral grafilerle değerlendirildi. Hastalar ve ebeveynlerine dirseğini tam aktif olarak ne kadar sürede hareket ettirebildiği ve tedavi sürecinden tatmin durumları sorularak kayit tutuldu.

BULGULAR: Ortalama kaynama süresi Grup I ve Grup 2 için sırasıyla 44 .I gün ve 46.3 gün, tam veya tama yakın dirsek hareketlerine kavuşma süresi Grup I ve Grup 2 için sırasıyla atel çıkarımı sonrası 57.5 ve 55.7 gün olarak bulundu. Grup I'deki 30 hastanın ve ebeveynin 2 I'i (\%70), Grup 2'deki sekiz hastanın ve ebeveynin altısı (\%75) sonuçtan tam olarak tatmin olduklarını ifade ettiler. Grup I'deki 30 hastanın 2l'i (\%70), Grup 2'deki sekiz hastanın ve altıı (\%75) her iki Flynn kriterlerine göre (kozmetik ve fonksiyonel) çok iyi grupta yer aldı.

TARTIŞMA: Pediatrik suprakondiler humerus kırıklarının tedavisinde kapalı redüksiyon ve perkütan çivilemenin altın standart tedavi olduğuna inanıyoruz. Bu metodun uygulanamadığı olgularda trisepsi kesen posterior yaklaşımın daha kolay kırık redüksiyonu ve muhtemelen daha kısa ameliyat süresi gibi avantajlarından dolayı güvenli ve lateral yaklaşımla karşılaştııllabilir olduğunu düşünüyoruz.

Anahtar sözcükler: Posterior yaklaşım; suprakondiler humerus kırı̆̆ı; triseps.

Ulus Travma Acil Cerrahi Derg 2016;22(5):483-488 doi: 10.5505/tjtes.2016.74606 